\title{
Compliance with Continuing Professional Development (IES7) of Internal Auditor and Quality of Internal Audit Function
}

\author{
Yaser Saleh AL frijat ${ }^{1}$ \\ ${ }^{1}$ Accounting Department, Business Faculty, Tafila Technical University, Jordan \\ Correspondence: Yaser Saleh Al frijat, Accounting Department, Business Faculty, Tafila Technical University, \\ Jordan. P. O. Box 179, Tafila 66110, Jordan.
}

Received: December 5, 2019

Accepted: December 28, 2019

Online Published: January 6, 2020

doi:10.5430/afr.v9n1p28

URL: https://doi.org/10.5430/afr.v9n1p28

\begin{abstract}
This paper aims to highlight the importance of compliance with continuing professional development (CPD) of internal auditors and its relationship to the quality of internal audit. The study utilised a Partial Least Squares Structural Equation Modelling (PLS-SEM), which emphasise on the analyses of regression and variance by distributing a questionnaire to the study sample of internal auditors in four countries (Jordan, Lebanon, Qatar and Kuwait), and the number of samples valid for statistical analysis reached 104. The paper has reached positive results regarding the importance of CPD in improving the quality of the internal audit, focused on the continuous follow-up to changes related to income and sales tax law, international financial reporting standards (IFRS), International Accounting Standards (IAS), and International Auditing Standards (IAS). Besides, modern Computer and Technological Applications in Internal audit practices and audit ethics. The results also indicated that CPD represents in professional skills is the development of skills to detect and combat theft and fraud, critical thinking skills of analyzed data. Original/Value, the CPD is the impulse by which internal auditors continue to learn new technical knowledge and skills that support them in professional work, to make them more qualified and developed in terms of knowledge and the skills needed within the labour markets.
\end{abstract}

Keywords: continuing professional development, professional competence, professional skills, internal auditor, internal audit quality

\section{Introduction}

Knowledge, professional skills and ethics in education curricula are still the backbone of the professions, and therefore their loss affects the nature of the professional competence of accountants. Which is reflected negatively on the outputs of accounting education, which makes us need to follow-up continuously in the process of development and continuing professional rehabilitation of accountants and auditors within the markets and institutions of employment.

Some consensus was indicating the ongoing development of accounting being a part of globalisation (De Lange et al., 2015). Filipe et al. (2014) indicate to CPD educational activities - not only to support the medical competence in medical knowledge and skills, but also in administration, technology, team building, professionalism, interpersonal communication, education, and accountability. Meanwhile, Laksmi (2015) notes CPD as a requirement of membership within several professions, accounting being one of such. Murphy \& Quinn (2018), viewed as a necessary component of ongoing education for accounting professionals. Additionally, high-quality CPD within accountants and auditors is seen as an enhancement of corporate reporting (Kaspina, 2015).

So, the continuous accounting education thus being a professional development activity based on the continuity of training, as well as on the creation of conditions for preparation and certification of highly qualified experts oriented to prolong their education (Kaspina, 2015). The accountancy profession must maintain a high degree of professional competence and lifelong learning if the professional accountant is to meet public expectations (IAESB 2015, IES7) since it operates in an environment of continual change. Indeed, a range of previous studies has focused on CPD as something very limited in developing countries.

As the vast majority of these past studies have focused on CPD and accounting education in the context of developed and developing countries (e.g., Albu et al. 2011a; Kavanagh \& Drennan, 2008; Ashworth \& Saxton, 1990; Al frijat, and Albawwat, 2019; Cervero, 2000; Daley, 1999; Paisey \& Paisey 2014; Kaspina, 2015; Zajkowski et al., 2007; 
Murphy \& Quinn 2018). Also, (Al frijat, \& Shbeilat 2016; Paisey et al., 2007; Paisey \& Paisey, 2018; Tudora, 2013; Chersan, 2019; Lee, 1995; Baker, 2005; Albu, et al., 2016).

Auditing is an integral part of the evolving systems of accountability and responsibilities within organizations, as well as society as a whole (IAESB, 2015, IES 8). Audit firms being described by researchers as key actors in coordinating accounting work, increasingly controlling the profession, and generating knowledge (Bakre, 2008; Botzem, 2014), as cited by Aburous (2019). What is the purpose of giving this importance to CPD?

The accountancy profession also operates in an environment of continuous change, meaning it must maintain a high degree of professional competence and lifelong learning in order for the professional accountant to meet public expectations (IAESB 2015, IES7). According to Murphy \& Quinn (2018), the role of education in the development of the accounting profession is also undeniable. Thus, the reason why CPD became a requirement for membership within many professions, including accounting, is becoming apparent (Laksmi, 2015).

In the context of today's dynamic and demanding economic environment, professional accountants face the requirement "to maintain competence and knowledge of current developments to enable them to act with due skill and care" (Howieson, 2003). And it is CPD that plays a vital role in maintaining the professional competence of accounting academics (Draz \& Ahmad, 2017). Notably, auditing is additionally an integral part of the evolving systems of accountability and responsibilities within organizations and society internationally (IAESB 2015, IES 8), recent accounting scandals have challenged and transformed the present-day role of auditors. Such events have, according to (Siriwardane et al. 2014), made it timely and essential to re-examine the skills, knowledge, and attitudes (SKAs) required of auditors within today's business environment — especially when also considering with the increased audit risk under IFRS (De George et al., 2016).

Other researchers Mattli \& Buthe, (2005) have begun to ask questions concerning the ability of accountants to comply with their duties in connection with the public interest and the social role of accounting; indeed, this has led to increasing concern about the future of the accounting profession, as cited by (Tudora, 2013). Furthermore, there is little research that has published from a historical perspective concerning education within the development of the accounting profession (Murphy \& Quinn, 2018). It is within an investigative study that the need for specific soft skills by novice auditors to relieve stress related to workplace CPE challenges, ultimately improving work readiness, was revealed (Plant et al., 2019). Indeed, an auditor requires public trust when doing his/her tasks, particularly when it comes to providing an audit service. Furthermore, according to Salehi et al. (2019), financial statement users must presume auditors as an independent party possessing sufficient experience and accountability, as this impact the users' perception of the quality of the audit services provided.

Further, the links between learning and the development of expertise require additional exploration (Daley, 1999). "To avoid professional obsolescence in knowledge and practical skills" according to Draz \& Ahmad (2017); "A special focus has been given to the instructional approaches of accounting professionals". And, indeed, there is a dearth of professional accounting education history literature within the Jordan context. It is along these lines that Aburous (2019) indicates the need to look into accounting education within Jordanian universities, as this has not updated in line with regulatory changes. In the same vein, modern studies commissioned by the ongoing education department at Qatar University point out that Qatar will require a comprehensive competencies reference frame for the analysis of persisting gaps that from an organizational viewpoint in order to respond to the development of the labour market (Weerakkody et al., 2016). Also, Al-khater \& Al-Kholi (2015) additionally indicating the presence of challenges facing accounting education within Qatar. Furthermore, there is, according to Majzoub \& Aga (2015), a wide gap between accounting education and accounting practice within Lebanon, De Lange et al. (2015) similarly noting significant differences in perceptions towards CPD offerings between professional accountants within developed economies compared with those of emerging economies.

\section{Theoretical Framework, Literature Review, and Research Hypotheses}

\subsection{Theoretical Framework and Literature Review}

Via the provision of extensive professional education and development opportunities - as well as supporting knowledge concerning internal auditing, risk management, governance, and control (https://Na.Theiia.Org). The mission of IIA is to provide dynamic leadership for the profession of internal auditing; all the central ideas of this article within the scope of the International Education Standards (IES7) is as follows.

"Scope of this Standard (IES7) prescribes the Continuing Professional Development (CPD) required for professional accountants to develop and maintain the professional competence necessary to provide 
high-quality services to clients, employers, and other stakeholders, and thereby to strengthen public trust in the profession".

Also evaluating the initial professional development related to technical competence, professional skills, and ethics, and other aspects concerned with the CPD of technical competencies and accountants' professional skills, several studies have highlighted the importance of International Accounting Education Standards (IAESs), (e.g., Ashworth \& Saxton, 1990; Cervero, 2000; Daley, 1999; Salehi et al., 2019; Paisey and \& Paisey, 2014; Kaspina, 2015; Murphy \& Quinn, 2018; Zajkowski et al., 2007; Halabi \& Chowdhury, 2018; Murphy, 2017; Paisey et al., 2007; Paisey \& Paisey, 2018; Tudora, 2013). It may be rather counterintuitive for some that the CPD stage's job in the creation of the officially qualified accountant is given a small amount of focus in the accounting field (Paisey and Paisey, 2014).

Due to the fact that this step is significantly more time-consuming than the others; indeed, non-ICT related skillsets are critical when it comes to modern-day qualified accountants within dynamic socio-technical settings, as pinpointed by (Douglas and Gammie, 2019).

It is along these lines that current accounting degrees have been negatively evaluated, as they have allegedly been unsuccessful in furthering such skillsets to the necessary extent. Indeed, as founded by Lee et al. (2016), professional development requires a lengthy educating process enhancing auditing skillsets, working procedures, and personal development. It was further demonstrated within a separate study by Lindsay (2016) that there is a clear link between long-term learning and CPD in terms of comprehending how the learning landscape has developed in ways concerning accounting and more. Indeed, accountant professors and professional accounting businesses will both be interested in and profit from the holistic model at hand, detailing today's continuous communications between both future and present accountants.

On this note, CPD's place within Qatar was investigated by Weerakkody et al. (2016) via the contrasting of it to that of the UK as a way to create a roadmap; this was done with the ultimate goal of creating a high-quality framework. As founded by Seol et al. (2011), surveys indicate that more personal expertise (i.e., fairness; honesty) could be considered as of higher importance and influence than those in the technical arena (i.e., tech communication). Furthermore, Bangladeshi accountants are showcased as experiencing more fulfilment in terms of the CPD within their career (Halabi and Chowdhury, 2018). This was specifically centring on the reasons for the creation of specific models more so than that of the models' groups themselves, Models of CPD: A Framework for Analysis was an article put forward by Kennedy (2014).

In the same vein, this is built upon in the findings citing the ways in which several elements of CPD policies may undergo evaluation in terms of what they show concerning professionalism's primary viewpoints (Kennedy, 2014). Meanwhile, within the research at hand, three overarching topics are discussed: the skills that will be necessary for the future; what business and accounting practice's future may entail; and the effects of education within the accounting district (Howieson, 2003).

According to Weerakkody et al. (2016), the UK and USA are two examples of first-world countries possessing high-rung continuous professional development frameworks within such careers, whilst lesser developed countries (such as Qatar) are currently still undergoing the initial stages for such framework implementation through a local lens. To comprehend this gap between countries Majzoub \& Aga (2015) put forward a framework via the evaluation of the professional accounting educational system, from the viewpoint of the IAES.

Meanwhile, a questionnaire conducted by Al-khater and Al-Kholi (2015) details the fact that there is a range of issues and trials in the Qatar education system via the requesting of the perspectives of respondents concerning the necessary skillset and expertise. One of these such issues is the fact that the expertise and skillsets acknowledged as the respondents allocated being of high essentiality as being of lesser importance than skills such as critical thinking and professional ethics.

As noted by Laksmi (2015), CPD denotes all tasks done within the education process to upkeep and further professional accountants' expertise, including informal and formal tasks (IFAC, 2004); such tasks have been undergone so as to enhance the execution of jobs within the professional context. In a similar vein, this CPE system's historical outbreak via a neo-institutional tactic has been evaluated by Murphy and Quinn (2018) the study pinpointing the emergence of some contradictions in terms of the institution itself, these were primarily as a result of skewed validity and interests and led to the ascendance of institutional change this ultimately ends up being one of the most important elements of CPE.

Remarkably, obtaining novel technical expertise in line with the career at hand is the primary intention of CPD implementation, and it is within this paper that any previously conducted research into the CPD of accounting 
academics will be examined (Draz and Ahmad, 2017).

According to IAESB (2015; A4), long-term education embodies all development and learning tasks; indeed, it also possesses several links to professional accountants, regardless of whether they are based within such fields. Furthermore, according to Collin et al. (2012), CPD and long-term education are how individuals can upkeep their career-related expertise and skillset. Meanwhile, Paisey and Paisey (2014) argue that professional development and learning should be considered as post- and pre-qualification development and learning (i.e., should be split into two separate components). Indeed, according to Paisey et al. (2007), CPD can be defined as the developmental and educational learning, and graft professionals complete post-graduation of their primary career-related qualification.

On the other hand, the study conducted by Howieson et al. (2014) identified in terms of skillsets and expertise in non-technical and technical arenas the roles employers and Universities play in such a field as accounting the literature review of this paper pinpointing the fact that University education-based critics tend to forget to mention the alterations that have been implemented within the accounting degree-related roles. In a separate study conducted by De Lange et al., (2015) professional accountants' varying viewpoints and practices in terms of the IES7 requirements (CPD) were established; ultimately, it was founded that requirements related to quality, experience, and the sufficient degree of CPD possessed the most varying viewpoints. Murphy (2017) meanwhile, in their study tackling the difference between such views, pinpointing the notable variations between procedures and viewpoints between the participants.

Notably, the primary objective of the investigation at hand in the study Kanjanapathy and Ramakrishnan (2018) is to explore the impact skills, knowledge, organisation commitment, and attitude on Malaysian accountants' ethical decision-making. This has been formulated on the grounds of the fact that previously researched within this field has showcased such elements as casting a positive impact on such a decision.

IAESB $(2015$, IES 8, 7) states: 'The aim of this IES 8 is to ensure that professional accountants acquire and maintain the specific capabilities required to work as competent audit professionals.' Such studies have primarily centred on public interest, as well as audit quality in the context of it being a significant goal of CPD (e.g., Paisey \& Paisey, 2018; Tudora, 2013; Mattli \& Buthe, 2005; Chersan, 2019; Lee, 1995; Baker, 2005). The body (IAESB) meanwhile indicates:

"The objective of an IFAC member body is to have professional accountants develop and maintain their competence sub-sequent to IPD through the undertaking of CPD that is necessary, in the public interest, and to provide high-quality services to meet the needs of clients, employers, and other stakeholders (IAESB, 2014)".

The personal characteristics of the engagement team, the culture and traits of the audit organisation, the helpfulness and capability of audit reports, the engagement team's features, and the elements beside auditor control potentially impacting the quality of audit are some of the audit quality outcomes, inputs and processes mirrored in the Financial Reporting Council's Audit Quality Framework (Bedard, 2010). Opening with an audit quality existing definition review - as well as some details concerning audit quality general frameworks-, the paper at hand puts forward a comprehensive summary of the audit quality at hand, (Knechel, et al. 2012). Jennifer \& Utke (2019) further indicating toward the notion of seasoned specialists generally producing higher-quality audits than other auditors (even after matching). Also, Albu et al., (2016) study are focused on the analysis of the internships' impact on the students' competencies and their image of accounting and audit.

While Anis (2017) investigates participant viewpoints on inconsistencies within accounting learning facilities, and how such inconsistencies may impact the quality of audit in the context of Egypt. Notably, a high negative link was found between such gaps in education and insufficient skillsets in terms of IT, decision-making capabilities, legal knowledge, critical thinking, suitable actions, problem-solving abilities, scripted communication, and financial capabilities within the latter study. Similarly, a separate study concluded there is an active link between audit quality and specialisation (Salehi et al., 2019), such a link-according to Jennifer and Utke (2019)—relying on the length of time spent of the auditor being in the specialist role. The extent to which CPD can safeguard the wants of the population is restricted due to the fact that the line separating an accountant's duty as an individual within their career and as a professional is unclear, as showcased by Paisey and Paisey (2018).

Training chances and organisational culture also being included in this, self-efficacy and professional progress both have the potential to considerably affect audit quality (Lee et al., 2016). When it comes to governing audit organisations and monetary auditors in enhancing their management skills in terms of improving service quality as well as in the governing of financial auditor bodies and statutory audit oversight bodies inconsistent expert training, an article penned by (Chersan, 2019). It is also detailed within this same article that it is essential to pinpoint the 
association between the determinants at hand and the financial auditor-provided services. Indeed, in this context, a key element of the process here is consistent auditor training, as their graduation relies on a proficient degree of training is obtained. In a separate study conducted in Král et al. (2017) show that there is a range of things to be looked into in terms of improvement in ICT skillsets, education necessities, practical know-how and professional expertise as well as their impacts and jobs within business CDP necessities and controllers' work possessing high-quality assurance.

The Competency Framework for Internal Auditing (at this moment abbreviated to CFIA) has been recently put forward by the Institute of Internal Auditors as a general overview of the capability requirements for all internal auditors the implementation of which is done according to (Seol et al., 2011) to attain high-scale career-related proficiency. It is on a similar note to this that separate research focusing on audit quality and consistent professional growth was conducted (Plant et al., 2019). As well as a range of others within this same field centring on sub-topics such as IT-related proficiency, CPD, and professional auditing skillsets (e.g., Kaspina, 2015; Firth et al., 2012; Seol et al. 2011; Lenz and Hanh, 2015; Král et al., 2017; Siriwardane et al., 2014; Ahmad et al., 2019).

Within the investigation as mentioned above, Plant et al. (2019) investigated new internal auditors', internal audit employers', and field representatives' (inhibiting clear-cut investments in CPE) perspectives, three issues common within the office being centred on lack of resources; problems in the environment; and varying forms of governing. These were all focused on to put into context some of the skills listed as necessary for people just going into the internal auditor position.

Plant et al. (2019) It is also studied that elements such as communication, malleability, time management skills, problem-solving abilities, group work and self-accountability were evaluated in order to understand further the executed jobs done to enhance the development of the required skills. Meanwhile, the necessity behind individuals possessing large financial and accounting reporting expertise within the practice in terms of creating suitable financial statements was highlighted by Albrecht et al. (2018). While Burton and Rezaee (1994) suggest the evaluation of such approaches for attaining long-term education-based CPD necessities for internal auditors. Auditor execution is highly impacted by self-driven efficiency and professional growth, as highlighted by (Lee et al. 2016)

The fact that the quality of the internal auditing employees at hand is one of the essential elements of a given organisation's internal audit functions is showcased in the study by (Seol et al. 2011). The theory of performance in establishing auditors' execution of work is most impacted by attitude, expertise, or knowledge also being explored by Ahmad et al. (2019) within this latter study; questionnaires were provided for auditors within Kuala Lumpur, the findings of which indicating such elements certainly being strongly linked to quality of work. Besides, the results of this investigation are of high importance to future researchers in the sense that it can act as a basis for future explorations within this sector.

When it comes to practitioners, governing bodies and presently used internal auditor choosing models, the reconsidering of these things within investigations are essential when it comes to evaluating internal auditors' perspectives on such skillsets (Seol et al., 2011); this is because such findings can help in the process of restructuring auditor-choosing procedures.

On a similar note, as founded by Kaspina (2015) the capability and accuracy of corporate management and monetary reporting can be furthered by adhering to the corresponding professional learning prerequisites; further, the enhancing of auditors and accountants training processes, the furthering of the workforce in terms of accounting personnel training, and the modernising of regulatory bodies training processes are some of the things required for the workforce to be effectively furthered. Furthermore, it was also established within the above study that CPD should be given to all employees, rather than just chief accountants.

Also, along these same lines, independency and professional qualifications within employees were additionally outlined by Firth et al. (2012) as being of strong influence over internal audit quality. The sample ranking audit evidence, professional reliability, and inquisitiveness, Siriwardane et al. (2014) queried Singaporean auditors in terms of their opinions on SKAs, particularly in terms of Entry-Level Auditors; (ELAs) SKA execution. Especially in the case of client business knowledge, the largest gap between predetermined importance and rankings of participants was in the field of business proficiency, such results affecting many accounting areas in the context of enhancing auditor proficiency.

From a study conducted by Tudora (2013), we can see that interest across the public is an essential element of the accounting career; this has been concluded due to the opinions derived from professionals. How this specific career has both disadvantaged and benefited public interest through CPD (particularly in terms of its policies and its 
promise to fulfil such public investment) is explored within Paisey and Paisey's (2018) study, the findings of which highlighting the inconsistencies within this profession, thus leading to disjointed, inconsistent promises and guidelines.

It is worth noting that the fact that public interest organisations have spread on an international scale has been kept in mind whilst completing this paper, as well as the fact that there is a range of ever-complicating hurdles auditors are being subjected to (Chersan 2019). On the grounds of the loose classifications of 'public interest' and what it entails, this research puts forward a public interest accounting conceptual framework, the aim of which being to detail the phenomenon of public interest from the perspectives of the involved parties and the individuals employed within the accounting sector (Turdora, 2013).

\subsection{Study Hypotheses}

The following hypotheses have been formulated in mind of the discussion of previous studies, as well as in mind of measuring the attainment of CPD within developing countries:

H1; Main hypothesis: The approach based on the Continuous Professional Development of internal auditors' technical competence contributes to the quality of internal audit function.

H11: The approach based on the Continuous Professional Development of internal auditors' technical competence in accounting and business contributes to the quality of internal audit function.

H12: The approach based on the Continuous Professional Development of internal auditors' technical competence in auditing contributes to the quality of internal audit function.

H13: The approach based on the Continuous Professional Development of internal auditor professional skills contributes to the quality of internal audit function.

\section{Research Methodology}

The Research Design of study implemented an approach in terms of its methodology, encompasses:

\subsection{Quantitative Questionnaire Design}

\subsubsection{Study Sample}

The study at hand evaluates the emphasis placed on compliance with Continuing Professional Education requirements to auditors and audit quality. In Table 1, the study was conducted with the aid of certified internal auditors from the four developing countries (Jordan, Lebanon, Qatar, and Kuwait), the sample internal auditors of which all having been chosen randomly. A total of 843 internal auditors were surveyed to collect data within the developing countries; further, the target sample was 211 responses, the response rate ultimately being placed at $113(54 \%)$. See below for further detail about society and samples concerning respondents.

Table 1. Society and Sample Study

\begin{tabular}{ccccccc}
\hline No. & Country & $\begin{array}{c}\text { No. of persons } \\
\text { with a certificate } \\
\text { CIA, CPA }\end{array}$ & $\begin{array}{c}\text { Target } \\
\text { Sample } \\
\text { percentage }\end{array}$ & $\begin{array}{c}\text { Target } \\
\text { Sample }\end{array}$ & $\begin{array}{c}\text { Response } \\
\text { rate }\end{array}$ & $\begin{array}{c}\text { Usable } \\
\text { responses }\end{array}$ \\
\hline 1 & Qatar & 247 & $25 \%$ & 62 & $(53 \%) 33$ & 29 \\
2 & Jordan & 132 & $25 \%$ & 33 & $(67 \%) 22$ & 22 \\
3 & Kuwait & 244 & $25 \%$ & 61 & $(52 \%) 31$ & 27 \\
4 & Lebanon & 220 & $25 \%$ & 55 & $(49 \%) 27$ & 26 \\
& Total & 843 & $100 \%$ & 211 & $(54 \%) 113$ & 104 \\
\hline
\end{tabular}

Note;

CIA; Certified Internal Auditor - Global

CPA; Certified Public Accountant - Global

\subsubsection{Personal Information}

Five reviewers examined the questionnaire paragraphs for reviewable in terms of the substance and format, all questionnaire questions having been derived from the content of the International Educational Standards.

See Table 2 (below) for a full analysis of the respondents' demographic information to the questionnaire paragraphs. 
Some notable statistics concerning this sample were as follows: $97 \%$ of them were males (indicating this profession has a very high association with the male sex); $62 \%$ were youths under the age of 35 , and $74 \%$ had a bachelor's degree in accounting. The majority of the respondents to the questionnaires were from Jordan, all working in private companies; furthermore, the role of an internal auditor may have the same name as a supervisor, manager, or head of an internal audit division. Finally, analysis showcased that the highest proportion of respondents had experience ranging from 10 to 20 years. See below for further details about personal information for respondents.

Table 2. Respondent Information

\begin{tabular}{|c|c|c|}
\hline & Demographic variable & Frequency (Percentage) \\
\hline \multirow[t]{2}{*}{ Gender } & Male & $(97 \%) 101$ \\
\hline & Female & $(3 \%) 3$ \\
\hline \multirow[t]{3}{*}{ Age } & Under 35 years & $(62 \%) 65$ \\
\hline & $35-55$ years & $(30 \%) 31$ \\
\hline & Above 55 years & $(8 \%) 8$ \\
\hline \multirow[t]{3}{*}{ Qualification } & $\mathrm{PhD}$ & $(8 \%) 8$ \\
\hline & Master & $(18 \%) 19$ \\
\hline & Bachelor & $(74 \%) 77$ \\
\hline \multirow[t]{4}{*}{ Country } & Jordan & $(31 \%) 33$ \\
\hline & Lebanon & $(20 \%) 20$ \\
\hline & Qatar & $(28 \%) 29$ \\
\hline & Kuwait & $(21 \%) 22$ \\
\hline \multirow[t]{4}{*}{ Position } & Internal Auditor & $(55 \%) 57$ \\
\hline & Audit Supervisor & $(22 \%) 23$ \\
\hline & Audit Manager & $(10 \%) 10$ \\
\hline & Audit chief & $(13 \%) 14$ \\
\hline \multirow[t]{5}{*}{ Experiences } & Less than ten years & $(34 \%) 35$ \\
\hline & 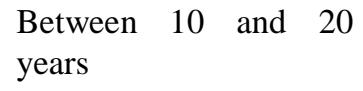 & $(46 \%) 48$ \\
\hline & $\begin{array}{l}\begin{array}{l}\text { Between } 20 \text { and } \\
\text { years }\end{array} \\
\end{array}$ & $(11 \%) 12$ \\
\hline & More than 30 years & $(9 \%) 9$ \\
\hline & Total & $104(\%$ 100) \\
\hline
\end{tabular}

\subsubsection{Cronbach's Alpha Test (Reliability Test)}

As can be seen in the table below 3 , the Cronbach's alpha value for all independent variables does not exceed 1 or 0.70 ; the internal consistency reliability, thus, is actively supported.

Table 3. Construct Reliability and Validity

\begin{tabular}{lccc}
\hline & Cronbach's Alpha & Composite Reliability & No. of items \\
\hline CPDAB; (H11) & 0.779 & 0.698 & 12 \\
CPDAU;(H12) & 0.723 & 0.754 & 13 \\
CPDPS;(H13) & 0.799 & 0.782 & 12 \\
QIAF; (Dependent Variable) & 0.774 & 0.824 & 3 \\
\hline
\end{tabular}

Please note that;

Independent variables

$C P D A B=$ The Continuing Professional Development of internal auditors' technical competence in accounting and business; (H11)

$C P D A U=$ The Continuing Professional Development of internal auditors' technical competence in auditing; (H12) 
$C P D P S=$ The Continuing Professional Development of internal auditor professional skills; (H13)

QIAF (Dependent Variable $)=$ The quality of the internal audit function.

\subsubsection{Descriptive Analysis}

H11: The approach based on the Continuous Professional Development of internal auditors' technical competence in accounting and business contributes to the quality of internal audit function.

As can be seen in Table below 4, the results of the respondents' survey showcased the arithmetic mean 4.0409 as possessing a clear correlation between professional development (in terms of the technical competence of internal auditors) and the quality of internal audit; further, it was also found that technical competence should include professional technical development in all areas of business whether administrative and relating to strategic planning, organizational behavior, financial management, production and operations or in economic and banking areas concerned with economic problems that must be followed up and paid attention to, including references in financial reporting provided by the internal auditor.

The solutions to this aspect of the study cast an impact on the results of the company's work, when taking into account the ongoing knowledge of changes that will occur and induce financial markets, whether global or local, that have an important link the internal auditor. in a similar vein, the technical accounting knowledge assigned to the internal auditor whether financial, tax, administrative, costs, and/or auditing is one of the strongest types of knowledge that must be followed by the internal auditor.

The professional development process of the internal auditor comes from attending courses and seminars - whether financial or non-financial - and participation within local and international conferences; it additionally comes from attending training courses to see the latest developments related to internal audit (which contributes to enhancing the quality of the internal audit). Interestingly, there is a keen interest in knowledge related to the dissemination of professional, scientific research within various subjects (including accounting, business, Finance, and Economics).

Table 4. Competence in Accounting, Business, and Quality of Internal Audit Function

\begin{tabular}{|c|c|}
\hline Items & Mean \\
\hline Continuous follow-up on amendments to the Income and Sales Tax. & 4.03846 \\
\hline $\begin{array}{l}\text { Continuous follow-up of changes in Corporate and Banks Law and Commercial } \\
\text { Law. }\end{array}$ & 4.29807 \\
\hline Continuous follow-up of changes to IFRS/IAS. & 3.42307 \\
\hline $\begin{array}{l}\text { The holding of continuous courses in the fields of inflation and unemployment in } \\
\text { order to identify solutions to these problems. }\end{array}$ & 3.98076 \\
\hline $\begin{array}{l}\text { Continuous follow-up of developments within the financial markets, investments, } \\
\text { changes in share prices, and in foreign exchange rates. }\end{array}$ & 4.25961 \\
\hline $\begin{array}{l}\text { Holding continuous courses in the fields of organisational behaviour, production, and } \\
\text { operations }\end{array}$ & 3.88461 \\
\hline Continuous availability of training opportunities, both on and off the job site. & 4.07692 \\
\hline $\begin{array}{l}\text { Continuous availability participation within local and international conferences } \\
\text { related to accounting. }\end{array}$ & 4.25 \\
\hline $\begin{array}{l}\text { Provision of the opportunity to attend workshops and seminars within the accounting } \\
\text { field. }\end{array}$ & 3.90384 \\
\hline The holding courses within the financial analysis. & 4.07692 \\
\hline The publication of research and scientific articles specialised in professional journals. & 4.25961 \\
\hline \multirow[t]{2}{*}{ The conduction of training workshops focusing on concepts related to objectivity. } & 3.91346 \\
\hline & 4.0409 \\
\hline
\end{tabular}

H12: The approach based on the Continuous Professional Development of internal auditors' technical competence in auditing contributes to the quality of internal audit function.

Table below 5 showcases an average value of 3.8732 further, there was a strong relationship between the CPD of the professional competence of the internal auditor and the improvement of the quality of internal audit, as showcased in 
the above test; this indicates that the CPD of training courses, lectures, and seminars on technical tax audits-as well as the continuous follow-up of changes to international auditing standards and the holding of courses in the field of business ethics audit—ensures any risks faced by companies are managed.

The internal auditor must additionally possess the most optimal practices within the work of internal audit. Furthermore, something else that contributes to the creation of an internal audit environment - thus meeting all the objectives the administration wants to reach, this in itself is an improvement within the internal audit quality-is the holding of training courses in the field of audit of information systems, information security, self-assessment of control, anti-money laundering, and project management. In order to drive this point home, it is important to note that, whenever the internal auditor has extensive technical knowledge in the internal audit work, there is a significant improvement in its performance, automatically reflecting on the internal audit quality.

Table 5. Competence in Auditing and the Quality of Internal Audit Function

\begin{tabular}{lc}
\hline \multicolumn{1}{c}{ Items } & Mean \\
\hline Continuous follow-up on amendments to the taxation audit. & 4.15384 \\
Continuous follow-up of changes within ISAs. & 4.29807 \\
Continuous follow-up of instructions related to corporate governance. & 3.38461 \\
$\begin{array}{l}\text { Continuous follow-up within a modern computer and technological applications in } \\
\text { internal audit practices. }\end{array}$ & 3.95192 \\
The holding of continuous courses in the field of audit ethics in work. & 4.13461 \\
The holding of continuous courses in methods of detecting, fraud, and theft. & 3.88461 \\
The holding of continuous courses in the methods of writing audit communication. & 4.02884 \\
The holding of training workshops in the field of government audit (public sector). & 3.48076 \\
The holding of training workshops in the field of information security. & 3.88461 \\
The holding of training workshops in the field of combating money laundering. & 3.52884 \\
Continuous planning based on the crisis- and risk management. & 3.64423 \\
The holding of training courses in the field of audit of information systems, & 3.86538 \\
information security, and self-assessment of control. & 4 \\
Organising training courses in combating money laundering and project management. & \\
\end{tabular}

H13: The approach based on the Continuous Professional Development of internal auditor professional skills contributes to the quality of internal audit function.

See Table below 6 for the results of the questionnaire analysis, which showcase the mean 3.8453 as well as the fact that there is a positive support by $80 \%$ the approach based on CPD of professional skills to be pursued and developed by the internal auditor; this is in terms of improving the quality of internal audit (i.e., whenever there is a development in the critical thinking skills of the data analysed by the auditor; in strategic and operational planning; in development and creativity skills; in management and supervisory skills; and whenever there is an improvement in the performance of the internal auditor, in turn contributing to the improvement of internal audit quality).

Besides, professional development takes place through the development of skills within crisis management potentially facing companies to overcome financial and non-financial risks; it is along these lines that the internal auditor requires the development of the skill of detecting financial and non-financial errors in order to enable them to control all theft and fraud the company faces. Furthermore, there is an additional need for skills to be developed by the auditor (e.g., persuasion and cooperation skills; emotional intelligence skills) so that effective communication skills can be developed, as well as skills including the using of tools and techniques of an automated audit. 
Table 6. Professional Skills and Quality of Internal Audit Function

\begin{tabular}{lc}
\hline \multicolumn{1}{c}{ Items } & Mean \\
\hline Develop the skill of detecting and combating theft and fraud. & 3.79807 \\
Develop the critical thinking skill in terms of the analysed data. & 3.81730 \\
Develop strategic and operational planning skills. & 3.66346 \\
Develop crisis management skills. & 3.57692 \\
Develop the technical analysis of financial statements skill. & 3.95192 \\
Develop managerial and supervisory skills. & 3.82692 \\
Enhance development and creativity skills. & 3.875 \\
Develop persuasion and cooperation skills. & 4.21153 \\
Develop emotional intelligence skills. & 3.55769 \\
Develop effective communication skills. & 3.97115 \\
Continuous professional development in using automated audit tools and & 3.86538 \\
techniques as a skill. & \\
Continuous professional development in the field of enterprise resource & 3.99038 \\
planning systems. & 3.842 \\
\hline
\end{tabular}

\subsection{Assessing the Structured Model (Hypothesis Testing)}

"The Partial Least Squares Structural Equation Modelling (PLS-SEM)", which emphasise on the analyses of regression and variance, was used and carried out by using the SmartPls software. There are two standard groups of statistical means for analysing the data among multiple variables, the first generation and the second generation techniques (Fornell, \& Bookstein,1982; Hair, et al., 2018). Notwithstanding the frequent use of the first generation techniques in social science researches, the second generation (structural equation modelling (SEM)) is used progressively more since the early 1990s. Even though first-generation techniques comprise highly developed approaches, such as logistical regression, multiple regression, analysis of variance, and exploratory factor analysis, it has some boundaries that cannot avoid in the present study. These boundaries include, amongst others, limited techniques to deal with complex model structure and to administer latent variables indirectly measured by a group of indicators. Besides, SEM techniques can model intricate interactions at once among multiple dependent and independent constructs (Haenlein \& Kaplan, 2004; Vinzi, et al., 2010).

\subsubsection{The study Model}

To theoretically clarify the underlying relationships between the independent and the dependent variables; the current study builds upon the results of previous studies. In this regards, some previous studies (e.g., Halabi \& Chowdhury, 2018; Murphy, 2017; Paisey et al., 2007; Paisey \& Paisey, 2018; Paisey and Paisey, 2014) indicated that the CPD of accounting, business and financial knowledge have a positive contribution to the quality of the internal audit; likewise, other studies (e.g., Paisey \& Paisey, 2018; Tudora, 2013; Mattli \& Buthe, 2005; Chersan, 2019; Lee, 1995; Baker, 2005) have indicated that the CPD of the technical competence of the financial auditing has an actual contribution to the quality of the internal audit. Furthermore, a group of studies (Seol et al., 2011; Plant et al., 2019; Kaspina, 2015; Firth et al., 2012; Lenz and Hanh, 2015; Král et al., 2017; Siriwardane et al., 2014; Ahmad et al., 2019) showed that the CPD of the professional skills of the internal auditors has a positive contribution to the quality of the internal audit. Accordingly, the present study suggests the below conceptual to overcome the inconsistency in previous and to facilitate the use of sophisticated analysis techniques (i.e. PLS-SEM). 


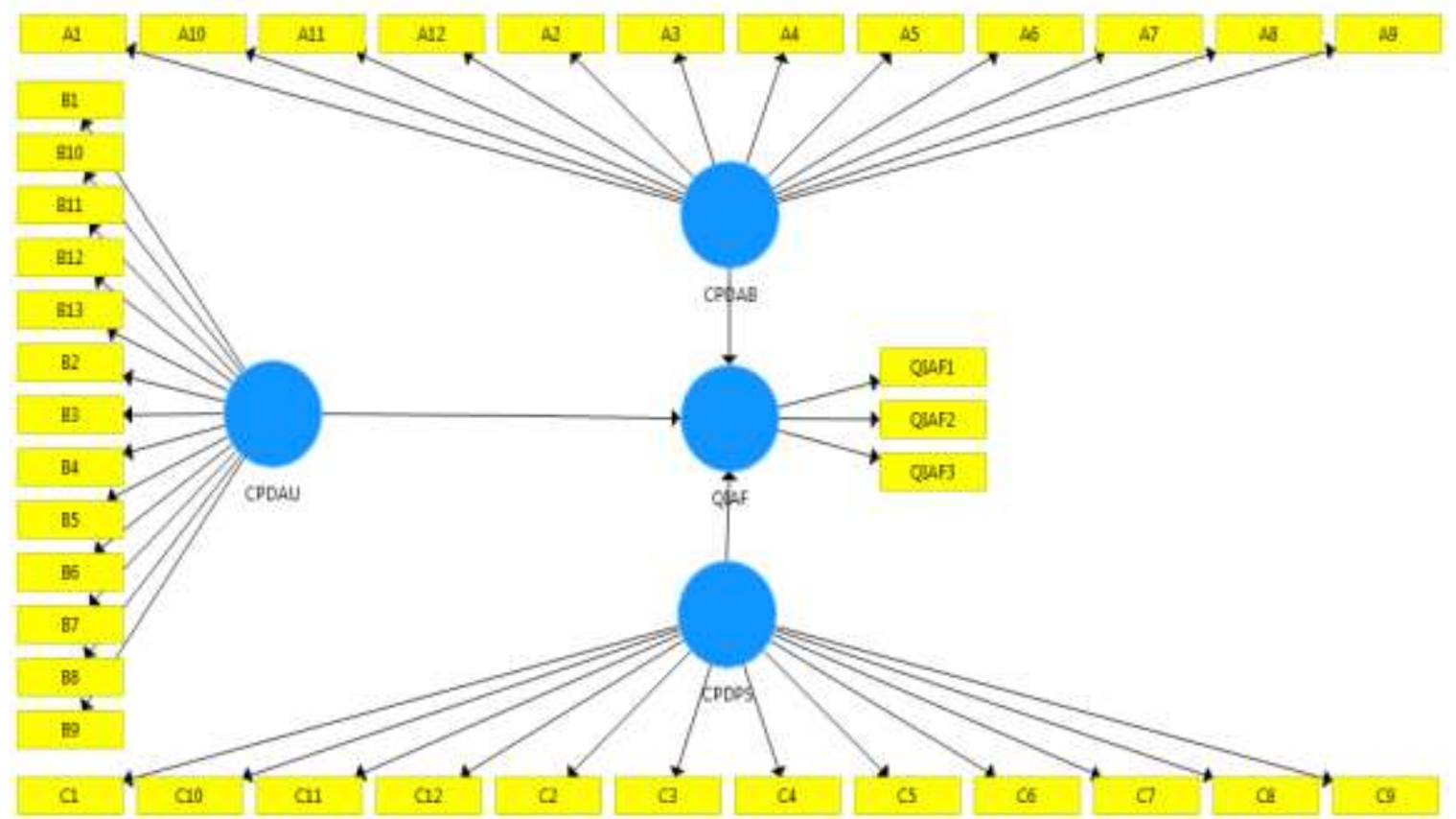

Figure 1. The study model

Please note that;

$C P D A B(H 11)=(A 1: A 12)$

$C P D A U(H 12)=(B 1: B 13)$

CPDPS $(H 13)=(C 1: C 12)$

QIAF $($ Dependent Variable $)=(Q I A F 1:$ QIAF3 $)$

\subsubsection{Outer Loadings}

The table below 7 shows the demonstration of the outer loading for the Model constructs of this research paper; for independent variables $\mathrm{H} 1, \mathrm{H} 2$, and $\mathrm{H} 3$ - as well as the dependent variable of the internal audit quality (QIAF1, QIAF2, and QIAF3). Notably, the recommended value for outer loading is 0.708 or higher, an outer loadings value of between 0.4 and 0.7 also being acceptable (Hair, 2018).

Table 7. Outer Loadings

\begin{tabular}{lcccc}
\hline & CPDAB & CPDAU & CPDPS & QIAF \\
H11 & H12 & H13 & \\
A1 & 0.709 & & \\
A2 & 0.959 & & \\
A3 & 0.894 & & \\
A4 & 0.664 & & \\
A5 & 0.897 & & \\
A6 & 0.744 & & \\
A7 & 0.665 & & \\
A8 & 0.780 & & \\
A9 & 0.877 & & \\
A10 & 0.959 & & \\
A11 & 0.795 & & \\
A12 & 0.664 & & \\
\hline
\end{tabular}




\begin{tabular}{|c|c|c|c|}
\hline B1 & 0.701 & & \\
\hline B2 & 0.740 & & \\
\hline B3 & 0.913 & & \\
\hline B4 & 0.864 & & \\
\hline B5 & 0.939 & & \\
\hline B6 & 0.583 & & \\
\hline B7 & 0.665 & & \\
\hline B8 & 0.724 & & \\
\hline B9 & 0.890 & & \\
\hline B10 & 0.765 & & \\
\hline B11 & 0.660 & & \\
\hline B12 & 0.622 & & \\
\hline B13 & 0.832 & & \\
\hline $\mathrm{C} 1$ & & 0.697 & \\
\hline $\mathrm{C} 2$ & & 0.774 & \\
\hline $\mathrm{C} 3$ & & 0.687 & \\
\hline $\mathrm{C} 4$ & & 0.749 & \\
\hline $\mathrm{C} 5$ & & 0.784 & \\
\hline C6 & & 0.860 & \\
\hline C7 & & 0.845 & \\
\hline C8 & & 0.744 & \\
\hline C9 & & 0.933 & \\
\hline $\mathrm{C} 10$ & & 0.682 & \\
\hline C11 & & 0.628 & \\
\hline $\mathrm{C} 12$ & & 0.699 & \\
\hline QIAF1 & & & 0.748 \\
\hline QIAF2 & & & 0.781 \\
\hline QIAF3 & & & 0.771 \\
\hline
\end{tabular}

Please note that

\section{Independent variables}

$C P D A B=$ The Continuing Professional Development of internal auditors' technical competence in accounting and business; (H11)

$C P D A U=$ The Continuing Professional Development of internal auditors' technical competence in auditing; (H12)

$C P D P S=$ The Continuing Professional Development of internal auditor professional skills; (H13)

QIAF (Dependent Variable) $=$ The quality of the internal audit function (QIAF1; QIAF2; and QIAF3)

3.2.3 Path Coefficients ( $\beta$ ), T-Values, and P-Values

Table 8 (below) showcases the results of the regression analysis for the cited study hypotheses, such results indicating a positive relationship between CPD and the quality of internal audit function. Indeed, the data collected in terms of our first hypothesis (H11) $(\beta=0.654, t=2.717$, $P$ Values. less 0.05$)$ indicate a positive relationship between Continuous Professional Development of internal auditors' technical competence in accounting and business and quality of internal audit function; leading from this, in terms of testing the second hypothesis (H12), the results indicate the overall model is statistically significant between Continuous Professional Development of internal auditors' technical competence when it comes to auditing and quality of internal audit function, whereby $(\beta=0.531$, $t=1.977$, P Values. less 0.05), thus supporting H12. Similarly, the results of test H13 in terms of Continuous Professional Development of internal auditor professional skills and quality of internal audit function are: $(\beta=0.547$, 
$t=1.991, P$ Values less 0.05). That means, not reject alternative hypotheses H11, H12 and H13.

Table 8. Path Coefficient ( $\beta$ ), T-Values, and P-Values

\begin{tabular}{ccccc}
\hline Variables & Path Coefficient $(\beta)$ & T Statistics & P Values & Decision \\
\hline $\begin{array}{c}\text { H11- CPDAB -> } \\
\text { QIAF1 }\end{array}$ & 0.654 & 2.717 & 0.001 & Supported \\
$\begin{array}{c}\text { H12- CPDAU -> } \\
\text { QIAF2 }\end{array}$ & 0.531 & 1.977 & 0.033 & Supported \\
$\begin{array}{c}\text { H13- CPDPS -> } \\
\text { QIAF3 }\end{array}$ & 0.547 & 1.991 & 0.044 & Supported \\
\hline
\end{tabular}

\subsubsection{Correlations Test and R-Square Test}

See Table 9 (below) for a demonstration of neither multi correlation problems between all independent variables, the high correlation value 0.612 indicating that this value was obtained from those studies; this, in turn, suggests the beginning of the multi correlation problem with $70 \%$.

Table 9. Latent Variable Correlations

\begin{tabular}{|c|c|c|c|c|}
\hline Variables & $\begin{array}{c}\text { CPDAB } \\
\text { H11 }\end{array}$ & $\begin{array}{c}\text { CPDAU } \\
\text { H12 }\end{array}$ & $\begin{array}{c}\text { CPDPS } \\
\text { H13 }\end{array}$ & $\begin{array}{c}\text { QIAF } \\
\text { Dependent } \\
\text { Variable }\end{array}$ \\
\hline CPDAB; (H11) & 1.000 & & & \\
\hline CPDAU;(H12) & 0.427 & 1.000 & & \\
\hline CPDPS;(H13) & 0.505 & 0.534 & 1.000 & \\
\hline QIAF; (Dependent Variable) & 0.937 & 0.923 & 0.612 & 1.000 \\
\hline
\end{tabular}

\section{$R$-Square Test}

As can be seen in Table 10 (below), the R-Square value has been utilised in order to measure the predictive power level of the model and, notably, the R-Square value of 0.75 can be categorised as substantial, whilst the value of 0.50 can be classed as a moderate and 0.25 as weak (Hair et al. 2018). Within the current research paper, Table 9 (see above) showcases that fact that the highest value of R-Square equal was 0.809. While R-Square Adjusted equated to 0.707. Such results suggest that the study Model produces a substantial amount.

Table 10. R Square and R Square Adjusted

\begin{tabular}{ccc}
\hline & R Square & R Square Adjusted \\
\hline QIAF & 0.809 & 0.707 \\
\hline
\end{tabular}

\section{Conclusion}

From all of the above, we can see that CPD is the motivation and means by which accountants and auditors continue to pursue learning and development post-completion of university education and entering the labour market. Indeed, we can deduct from this that there is a necessity for CPD implementation, as it drives us to learn new technical knowledge and skills that support our work - thus making us more qualified in terms of accounting knowledge and the skills needed within the relevant labour markets. The sample was chosen from these countries because it is the highest Arab countries in the professional internal auditors who obtained the certificate of the internal auditor.

Whether medical, engineering, administrative, or social, several studies indicated to the importance of learning and education in terms of improving and developing the performance of many institutions and companies managed by scientifically and practically qualified individuals. Indeed, performance improvement has been founded to be based on the improvement of the progress of these professions, as well as in achieving the goals set by companies. Within this particular study, we examined the importance of CPD in improving the internal auditing quality, meaning the focus largely centred on the aspect of internal auditing; this is due to the fact that it has become one of the required professions of the labour market and is in the interest of shareholders within all companies. That is since it demonstrates real facts related to the performance of such companies in a very objective and transparent manner. This study additionally focuses on important aspects related to the CPD of technical competencies, as well as the 
professional skills that must be committed by the internal auditor in order to upgrade this profession, in accordance with the (IES 7). Such competencies and skills can be achieved only via CPD.

The study focused on obtaining accurate data and information, distributing a questionnaire to several internal auditors within the countries. The study reached positive results in terms of the importance and role of CPD in improving the performance represented by the quality of the internal audit. It was additionally founded during this study that professional development within the technical competencies represented by continuous follow-up on amendments to the Income and Sales Tax, as well as changes in Corporate and Banks Law, commercial law, IFRS/IAS/ISAs, corporate governance, in modern computer and technological applications in the internal audit practices, and audit ethics was paramount for optimal performance, as well as consistent follow-ups of developments within the financial markets, investments, changes in share prices, and foreign exchange rates. These factors play a key role in achieving the desired internal audit quality.

It is also important to note that the results additionally indicated toward professional development in the following professional skills: the development of detecting and combating theft and fraud skills, critical thinking of data, strategic and operational planning, crisis management, and creativity - not to mention development of persuasion and cooperation skills, emotional intelligence, effective communication, and the using of automated audit tools and techniques. All of the above play a significant role in the quality of internal audit, as do general international professional certificates, specialisation, and subsidiary, all of which aiding in raising the level of technical knowledge of internal auditors (e.g., information security certification; systems audit (CISA); financial services (CFSA); government audit (CGAP); anti-money laundering (CAMS); and project management (PMP).

On the grounds of the above findings, the researcher has formed a list of recommendations regarding the Continuous Professional Development of the internal auditor to work to communicate and cooperate effectively between the internal audit associations within the discussed countries, as well as in the Institute of Internal Auditors in America. This cooperation includes both assisting internal auditors in providing courses and seminars and participating in conferences related to the development of the internal audit profession.

As well as the above, when it comes to all internal auditors in the world, the IIA within the US should impose more control over the renewal of membership; furthermore, the researcher is additionally interested in recommending the issuance of monthly professional, scientific journals (refereed by specialised committees and distributed to internal auditors within each country at nominal prices) to the heads and members of the internal audit associations. Additionally, they must be members of professional associations to follow up on all the changes and developments that occur, as well as, in return for financial fees charged by the associations, the work of mandatory courses for internal auditors. As well as this, training opportunities for internal auditors should be supervised by these associations, whether internal or external, the researcher also recommending the IIA to increase the number of training hours required to renew the membership of the profession. It is also recommended that internal auditors should commit to an annual professional exam held by international experts in the scope of internal audit and be encouraged to attend training courses related to professional certificates approved for internal auditors.

\section{References}

Aburous, D. (2019). IFRS and institutional work in the accounting domain. Critical Perspectives on Accounting, 62, pp. 1-15. https://doi.org/10.1016/j.cpa.2018.10.001

Ahmad, S. R., Hariri, H. Zawawi, S., \& Hassan, R. (2019). Determinants of Auditors' Work Performance. International Journal of Financial Research, 10, (3). https://doi.org/10.5430/ijfr.v10n3p230

Albrecht, A., Mauldin, E. G., \& Newton, N. J. (2018). Do Auditors Recognize the Potential Dark Side of Executives' Accounting Competence? The Accounting Review: November 2018, 93(6), 1-28. https://doi.org/10.2308/accr-52028.

Albu, N., Artemisa Calu, D., and Guşe, G. R. (2016). The role of accounting internships in preparing students' transition from school to active life. Accounting and Management Information Systems, 15(1), 131-153, 2016.

Albu, C.N., Albu, N., Faff, R., \& Hodgson, A. (2011a). Accounting competencies and the changing role of accountants in emerging economies. The case of Romania. Accounting in Europe, 8(2), 155-184. https://doi.org/10.1080/17449480.2011.621395

Al frijat, Y., \& Shbeilat, M. (2016). Jordanian Universities and Their Role in the Trend towards the Development of Technical Competence for Accounting Learning Outcomes in Line with IES \#2. Accounting and Finance Research, 5(2), 231-238. https://doi.org/10.5430/afr.v5n2p20 
Al frijat, Y., \& Albawwat, I. (2019). Values, ethics, and attitudes (IES 4) and earnings management from the viewpoint of the financial accountants at Amman Stock Exchange. Journal of Accounting and Management Information Systems, 18( 3), 379-398. https://doi.org/10.24818/jamis.2019.03004

Al-khater, k., \& Al-Kholi, N. (2015). The current status of accounting Education Knowledge and skills required for Qatari market. The journal of accounting, 18(1), 65-89. https://doi.org/10.12785/AJA/180103

Anis, A. (2017). Auditors' and accounting educators' perceptions of accounting education gaps and audit quality in Egypt'. Journal of Accounting in Emerging Economies, 7(3), 337-351. https://doi.org/10.1108/JAEE-08-2016-0070

Ashworth P., \& Saxton J. (1990). On 'Competence'. Journal of Further and Higher Education, 14(2), 3-25. https://doi.org/10.1080/0309877900140201

Bakre, O. M. (2008). Financial reporting as technology that supports and sustains imperial expansion, maintenance and control in the colonial and postcolonial globalisation: The case of the Jamaican economy. Critical Perspectives on Accounting, 19(4), 487-522. https://doi.org/10.1016/j.cpa.2006.09.002

Bedard, J. C., Johnstone, K. M., \& Smith, E. F. (2010). Audit Quality Indicators: A Status Update on Possible Public Disclosures and Insights from Audit Practice. Current Issues in Auditing American Accounting Association, 4(1), 12-19. https://doi.org/10.2308/ciia.2010.4.1.C12

Botzem, S. (2014). Transnational standard setting in accounting: Organizing expertise-based self-regulation in times of crises. Accounting, Auditing \& Accountability Journal, 27(6), 933-955. https://doi.org/10.1108/AAAJ-04-2013-1301

Burton, E., \& Rezaee, Z. (1994). University based Lifelong Continued Professional Development (CPD) for Internal Auditors. Managerial Auditing Journal, 9(2), 32-36. https://doi.org/10.1108/02686909410053575.

Cervero R. M. (2000). Trends and issues in continuing professional education. New Directions for Adult \& Continuing Education. No. 86, pp. 3-12. https://doi.org/10.1002/ace.8601

Chersan, I. C. (2019). Audit Quality and Several of Its Determinants. Audit Financier, 1(153), 93-105, https://doi.org/10.20869/AUDITF/2019/153/002

Collin, K. der Heijden, B. V., \& Lewis, P. (2012). Continuing professional development". International Journal of Training and Development, 16(3), 155-163. https://doi.org/10.1111/j.1468-2419.2012.00410.x

Daley B. J. (1999). Novice to expert: An exploration of how professionals learn. Adult Education Quarterly, 9(4), 133-147 https://doi.org/10.1177/074171369904900401

Douglas, S., \& Gammie, E. (2019). An investigation into the development of non-technical skills by undergraduate $\begin{array}{lllll}\text { accounting } & \text { programmers. Journal } & \text { Accounting }\end{array}$ https://doi.org/10.1080/09639284.2019.1605532

Draz, M., \& Ahmad F. (2017). Continuing Professional Development and Accounting Academics: A Literature Review. International Journal of Learning and Development, 7(4), 44-52. https://doi.org/10.5296/ijld.v7i4.12089

De George, E. T., Li, Xi, \& Shivakumar, L. (2016). A review of the IFRS adoption literature. Review of Accounting Studies, 21(3), 898-1004. ISSN 1380-6653 https://doi.org/10.1007/s11142-016-9363-1

De lange, P., JACKLING, B., \& SUWARDY, T. (2015). Continuing Professional Development in the Accounting Profession: Practices and Perceptions from the Asia Pacific Region. Accounting Education, 24(1), 41-56 https://doi.org/10.1080/09639284.2014.1002800.

Filipe, H. P., Silva, E. D., Stulting, A., \& Golnik, K. C. (2014). Continuing Professional Development: Best Practices. Middle East African Journal of Ophthalmology, 21(2), 134-141 https://doi.org/10.4103/0974-9233.129760

Firth, M., Rui, O.M., \& Wu, X. (2012). How do various forms of auditor rotation affect audit quality? Evidence from China. The International Journal of Accounting, 47(1), 109-138. https://doi.org/10.1016/j.intacc.2011.12.006

Fornell, C., \& Bookstein, F. (1982). Two Structural Equation Models: LISREL and PLS Applied to Consumer Exit-Voice Theory. Journal of Marketing Research, 19(4), 440-452. https://doi.org/10.2307/3151718

Haenlein, M., \& Kaplan, A. M. (2004). A beginner's guide to partial least squares (PLS) analysis. Understanding Statistics, 3, 283-297. https://doi.org/10.1207/s15328031us0304_4

Hair, J. E., Hufit, G. M., Ringle, C. M., \& Sarstedt, M. (2018). A primer on partial least squares structural equation 
modeling. PLS-SEM. 3nd ed. USA: SAGE Publications. https://doi.org/10.3926/oss.37

Halabi, A., \& Chowdhury, M. S. (2018). Bangladesh accountants and Continuing Professional Development: Views from a less developed country. Journal of Accounting in Emerging Economies, 8(4), 514-526, https://doi.org/10.1108/JAEE-12-2017-0123.

Howieson, B. (2003). Accounting practice in the new millennium: Is accounting education ready to meet the challenge? British Accounting Review, 35(2), 69-103. https://doi.org/10.1016/S0890-8389(03)00004-0

Howieson, B., Hancock, P., Segal, N., Kavanagh, M., Tempone, I., \& Kent, J. (2014). Who should teach what? Australian perceptions of the roles of universities and practice in the education of professional accountants. Journal of Accounting Education, 32(3), 259-275. https://doi.org/10.1016/j.jaccedu.2014.05.001

IAESB. (2014). International education standard (IES7): Continuing professional development. In Handbook of International Education

Pronouncements. https://www.ifac.org/publications-resources/2014-handbook-international-education-pronouncements.

IAESB (2015). Framework for international education standards for professional accountants and aspiring professional accountants. In Handbook of international education pronouncements (pp. 5-24). https://www.ifac.org/publications-resources/2015-handbook-international-education-pronouncements.

IAESB. (2017). Proposed International Education Standard (IES7): Continuing Professional Development (Revised), available https://www.ifac.org/publications-resources/proposed-international-education-standard-7-continuing-professional (Accessed 20 June, 2017).

IFAC. (2004). International Education Standard, Continuing Professional Development (IES7): a program of lifelong learning and continuing development of professional competence, International Federation of Accountants.

IIA, The Institute of Internal Auditors (IIA) is an international professional association with global headquarters in Lake Mary, Florida, USA. https://Na.Theiia.Org.

Jennifer G., \& Utke S. (2019). Audit Quality and Specialist Tenure. The Accounting Review, 94(3), 113-147. https://doi.org/10.2308/accr-52206

Kanjanapathy, M., \& Ramakrishnan, S. (2018). The Influence of Knowledge, Skills, Attitude and Organization Commitment Using Ethical Climate as A Moderator Towards Ethical Decision Making of Accountants in Malaysia: A Conceptual Paper. International Journal of Engineering \& Technology, 7 (2.29) (2018), 1155-1160. https://doi.org/10.14419/ijet.v7i2.29.15148

Kaspina, R. (2015). Continuing Professional Development of Accounting and Auditing: Russian Experience and Challenges. Social and Behavioral Sciences, 191(2015), 550 - 553. https://doi.org/10.1016/j.sbspro.2015.05.110

Kavanagh, M. H., \& Drennan, L. (2008). What skills and attributes does an accounting graduate need? Evidence from student perceptions and employer expectations. Accounting \& Finance, 48(2), pp. 279-300. https://doi.org/10.1111/j.1467-629X.2007.00245.x

Kennedy, A. (2014). Understanding continuing professional development: the need for theory to impact on policy and practice. Professional Development in Education, 40(5), 688-697. https://doi.org/10.1080/19415257.2014.955122

Knechel, W. R., Krishnan, G. V., Pevzner, M., Shefchik, L., \& Velury, U. (2012). Audit Quality: Insights from the Academic Literature. Auditing A Journal of Practice \& Theory, 32. https://www.researchgate.net/publication/256017547. https://doi.org/10.2139/ssrn.2040754

Král, B. Mikołajewicz, G. Nowicki, J., \& Šoljaková, L. (2017). Professional competences of controllers: The case of Poland. European Financial and Accounting Journal, 12(2), 17-40, http://dx.doi.org/10.18267/j.efaj.179.

Laksmi, A. C. (2015). Continuing professional development for the auditing profession: Evidence from Indonesia. A thesis submitted in fulfilment of the requirements for the degree of Doctor of Philosophy, RMIT University.

Lee, T. (1995). The professionalization of accountancy: a history of protecting the public interest in a self-interested way. Accounting, Auditing \& Accountability Journal, 8(4), 48-69. https://doi.org/10.1108/09513579510100725.

Lee, S. C., Su, J. M., Tsai, S. B., Lu, T. L., \& Dong, W. (2016). A comprehensive survey of government auditors' self-efficacy and professional development for improving audit quality. Springer plus, 5, 1263. https://doi.org/10.1186/s40064-016-2903-0

Lenz, R., \& Hahn, U. (2015). A synthesis of empirical internal audit effectiveness literature pointing to new research 
opportunities. Managerial Auditing Journal, 30(1), 5-33. https://doi.org/10.1108/MAJ-08-2014-1072

Lindsay, H. (2016). More than 'continuing professional development': A proposed new learning framework for professional accountants. Accounting Education: An International Journal, 25, 1-13. https://doi.org/10.1080/09639284.2015.1104641

Majzoub, S., \& Aga, M. (2015). Characterizing the Gap between Accounting Education and Practice: Evidence from Lebanon. International Journal of Business and Management, 10(12), 127. https://doi.org/10.5539/ijbm.v10n12p127

Mattli, W., \& Buthe, T. (2005). Accountability in Accounting? The Politics of Private Rule-Making in the Public Interest. Governance An International Journal of Policy Administration and Institution, 18(3), 399-429. https://doi.org/10.1111/j.1468-0491.2005.00282.x

Murphy, B., \& Quinn, M. (2018). The emergence of mandatory continuing professional education at the Institute of Certified Public Accountants in Ireland. Accounting History, 23(1-2), 93-116. https://doi.org/10.1177/1032373217731124

Murphy, B. (2017). Professional competence and continuing professional development in accounting: professional $\begin{array}{lllll}\text { practice vs. } \quad \text { non-practice. } & \text { Accounting } & \text { Education, } & \end{array}$ https://doi.org/10.1080/09639284.2016.1218780

Paisey, C., Paisey, N. J., \& Tarbert, H. (2007). Continuing Professional Development Activities of UK Accountants in Public Practice. Accounting Education, 16(4), 379-403, https://doi.org/10.1080/09639280701646554

Paisey, C., \& Paisey, N. J. (2018). Protecting the public interest? Continuing professional development policies and role-profession conflict in accountancy. Critical Perspectives on Accounting, (2018). https://doi.org/10.1016/j.cpa.2018.04.002.

Paisey, C., \& Paisey, N. J. (2014). The state of professional education and training. In: Wilson, R. M.S. (ed.) The Routledge Companion to Accounting Education. Series: Routledge Companions in Business, Management and Accounting. Routledge: Abingdon, pp. 673-696. ISBN 9780415697330.

Plant, K., Barac, K., \& Sarens, G. (2019). Preparing work-ready graduates - skills development lessons learnt from internal audit practice. Journal of accounting education, 48, September 2019, Pp. 33-47. https://doi.org/10.1016/j.jaccedu.2019.06.001.

Salehi, M., Mahmoudi, M. R., \& Daemi Gah, A. (2019). A meta-analysis approach for determinants of effective factors on audit quality: Evidence from emerging market. Journal of Accounting in Emerging Economies, 9(2), 287-312. https://doi.org/10.1108/JAEE-03-2018-0025.

Seol, I., Sarkis, J., \& Lefley, F. (2011). Factor structure of the competency framework for internal auditing (CFIA) skills for entering level internal auditors. International Journal of Auditing, 15(3), 1-13. https://doi.org/10.1111/j.1099-1123.2011.00431.x.

Siriwardane, H., Hoi Hu, B. K., \& Low, Y. (2014). Skills, Knowledge, and Attitudes Important for Present-Day Auditors. International Journal of auditing, 18(3), 193-205. https://doi.org/10.1111/ijau.12023.

Tudora, A. T. (2013). Balancing the Public and the Private Interest - A Dilemma of Accounting Profession. Procedia-Social and Behavioral Sciences, 92 (2013), 930-935. https://doi.org/10.1016/j.sbspro.2013.08.779

Vinzi, V. E., Trinchera, L., \& Amato, S. (2010). PLS Path Modeling: From Foundations to Recent Developments and Open Issues for Model Assessment and Improvement. Handbook of Partial Least Squares, Springer Handbooks of Computational Statistics (pp. 47- 82). https://doi.org/10.1007/978-3-540-32827-8_3

Weerakkody, V., Osmani, M. Waller, P. Hindi, N., \& Al-Esmail, R. (2016). Situating Continuing Professional Development in Life Long Learning in Qatar. International Journal of Business and Management, 11(11). https://doi.org/10.5539/ijbm.v11n11p81

Zajkowski, M., Sampson, V., \& Davis, D. (2007). Continuing Professional Development: perceptions from New Zealand and Australian accounting academics. Accounting Education: An International Journal, 16(40), 405-420. https://doi.org/10.1080/09639280701646588 